\title{
Sciendo
}

\section{Necessity and Determinism in Robert Grosseteste's De libero arbitrio}

\author{
Marcin Trepczyński \\ University of Warsaw \\ Krakowskie Przedmieście 3 Street \\ 00-927 Warsaw, Poland \\ e-mail: m.trepczynski@uw.edu.pl
}

\begin{abstract}
:
In this paper, the theory of necessity proposed by Robert Grosseteste is presented. After showing the wide range of various kinds of determination discussed by him (connected with: (1) one's knowledge about the future, (2) predestination, (3) fate, (4) grace, (5) sin and temptation), a different context of Grosseteste's use of the notion of necessity is analyzed (within logical and metaphysical approaches). At the heart of his theory lie: the definition of necessity, which is that something lacks the capacity (posse) for its opposite, and the distinction between two perspectives within which we can consider necessity: (1) the one according to which the truthfulness of a dictum determines that it cannot be the opposite, (2) a pre- or atemporal one, as if something had not yet begun. On these grounds, Robert explains that God's omniscience is compatible with contingency, including human free decisions. Robert's theory is still relevant and useful in contemporary debates, as it can provide strong arguments and enrich discussions, thanks to the twoperspectives approach, which generates nine kinds of positions on the spectrum of determinism and indeterminism.

Keywords: necessity, contingency, determination, God's omniscience, future contingents, Robert Grosseteste, Jan Woleński.
\end{abstract}

\section{Introduction}

The concepts of necessity and determinism belong to those philosophical problems which seem to be "immortal": they are discussed by subsequent generations of thinkers, and it is highly likely that they will keep coming back, inspiring philosophers to reconsider them and formulate new insights. Professor Jan Woleński is one of those philosophers who have made successful attempts at discussing these issues and presenting them as clearly as possible. He has accomplished this task both in the context of the problem of free will [27] and within his analysis concerning the topic of the determination of the past and the future [26]. The latter was conducted as part of a discussion inspired by the book by Marcin Tkaczyk on future contingents [21]. Numerous replies and polemics (e.g. [17], [16], [9]) produced in response to 
this book, as well as other recently published papers (see e.g. [3], [4], [7], [8], [22]), reveal that this topic is still vivid.

However, it is very important to keep in mind former discussions on those issues, including analyses conducted by ancient and medieval philosophers who have provided foundations for later debates (cf. [12]), at least for two reasons. First, we should not neglect the historical approach and instead present the development of ideas and problems in their historical context in order to properly understand the current debates, which are more or less shaped by the past. Second, it is important to accumulate knowledge, including various results obtained by classic authors, since they provide very interesting and inspiring approaches, as was, for instance, the case with Jan Łukasiewicz's proposals concerning the determination of the future, especially his three-valued logic, inspired by Aristotle's Peri hermeneias IX with its famous example of the sea battle. What is more, it seems that medieval thinkers were the ones who established the main approaches to the topic of future contingents (cf. [25]). In this light it is worth collecting and analyzing such approaches, both those leading and those less popular, especially since they can still provide us with new solutions. Among recent findings which revealed a worthwhile contribution of medieval thought to such problems were the applications of a version of the principle of the necessity of the past from the works of 12thcentury philosophers identified by Wojciech Wciórka, labelled by this author as the "restricted necessity of the past" (RNP), according to which "Every true dictum about the past whose truth does not depend on the future is necessary" [24].

In this article, I would like to present the concept of necessity formulated by Robert Grosseteste (ca. 1168 - 1253) in his work De libero arbitrio (On Free Decision). I will argue that his approach is an important and inspiring contribution to the discussions on necessity and determinism. What is more, I will show that it can also be useful in contemporary debates, by referring to some issues discussed by Professor Woleński.

Robert Grosseteste was one of the most outstanding thinkers of the Middle Ages, known especially for his treatise De luce (On Light) in which he claimed that light is the first corporeal form (so every material thing is somehow made of light) and that at the beginning there was a point of light that infinitely multiplied, by auto-diffusion "producing dimensions of space and subsequent beings" [5, p. 104], that is - the world. He is also famous for being one of the first promoters of experimental methods in medieval science. Less known, yet very influential, "penetrating and original" [13, p. 1], is his work De libero arbitrio in which he conducts subtle analyses concerning free will or, to be precise: free decision. After Ludwig Baur's edition from 1912, a critical edition of two recensions of this work with English translation has been published in 2017 by Neil Lewis [18], and there are still few studies on this treatise (the most important are: [6], [13], [15]), despite it being very worthy of attention. Thus, it is especially great to see that this work has recently been singled out by Agnieszka Kijewska, who has perfectly presented Grosseteste's concept of free will and his arguments for the compatibility of freedom of will and God's foreknowledge in the volume If God exists..., in a separate chapter [11]. I would like to add to the above-mentioned studies some remarks focusing on the concepts of necessity and determinism. My reflections will be based on Lewis's edition of the later recension, referred to by Baur as recension I, which is the complete one [14, pp. xiv, xix]; however, I will also refer to a crucial point of the earlier recension. When citing this edition, I will give page numbers only; I will quote the Latin version when it is important to show the original wording.

\section{Kinds of Determination}

As Agnieszka Kijewska [11, pp. 136-137] rightly points out, in De libero arbitrio, Robert Grosseteste uses Aristotle's method of analysis (described in Posterior Analytics), which 
requires sorting issues by four questions related to the four things we seek: (1) the fact (oti), (2) the reason why (dioti), (3) whether it is (ei esti), (4) what it is (ti esti). Before asking what is (quid sit) freedom of decision (chapters 16-19), he decides to analyze whether there is anything like free decision (an sit), and to finally (in chapters 20-21) ask about its features, such as what it derives from ( $a$ quo). Thus, in the introductory sentence he indicates that, first of all, it should be asked: Is there liberum arbitrium (hereinafter: LA) at all? And he enumerates possible factors which can "destroy" LA, like: "God's foreknowledge and predestination, the truth of a dictum about the future, divination and prophecy, the necessity of fate, grace, and the compulsion to sin that stems from temptation or some kind of force," and "our sinning by means of free decision," as well as "other things that do not come to our mind right now" [p. 109]. These "factors" and their relation to the necessity of future events are analyzed by Robert in subsequent chapters of the first part devoted to the topic of the existence of LA.

When we compare the above-mentioned enumeration and the content of these chapters, we can see that he distinguishes at least five different kinds of determination of future events:

1) someone knows the future (it includes the case of the truth of a dictum about the future), so it is determined;

2) God predestines someone, so the effect of predestination is determined;

3) there is fate, so it determines the future;

4) grace makes a deed meritorious totally, so it is thoroughly determined as meritorious;

5) if sin dominates in a human being, it determines that he/she does evil.

Let us note that Grosseteste offers here a really wide range of possible kinds of determination and that they are really diverse. What is more, this list is not necessarily exhaustive, as he is aware that there can be other possible factors that destroy LA. The case marked as (1) represents determination which is not connected with any action or any property of being. It is based on someone's knowledge only. Case (2) refers to God's will and decision which produces a real effect in someone. Case (3) assumes a power ruling all reality in a certain way which cannot be changed. Finally, (4) and (5) refer to the theological reality in which grace or sin can force the human being into some state, and it is impossible for him/her to change it by his/her own, natural powers; yet the two situations are different: grace is given by God, whereas sin is in the human being, and grace not only causes the human being to be able to do good, as it is possible without grace, but it also makes deeds meritorious - thus, it is not just a simple opposition to evil done under the influence of sin.

The most extensive analyses provided by Grosseteste concern the first kind of determination (chapters $1-8$ ). Next, Robert briefly deals with: predestination (chapter 9), grace (chapter 10), fate (chapter 11) and sin (chapters 12 - 13). It proves that the first kind of determination, marked above as (1), seems to him to be the most problematic one. And, to anticipate further presentation, we can say that it is with (1) that the most important considerations on necessity are connected. What is more, (1) significantly differs from other kinds of determination. The latter are related to mechanisms to which our actions are subjected (effects of fate, grace, sin) or with God's acts of will (decision to predestine someone). They are supposed to (directly or indirectly) determine some events. It means that there is a kind of causal connection between determinants and determined events; however, this connection may be non-physical. It can be an influence of a supernatural character, as in the case of grace or sin. Therefore, we are speaking here about a broad understanding of cause - it could be an event such as God's decision or human sin, and it could produce another event as a result. On the contrary, in (1) there is no connection based on which a certain event would be a result, and in this way would be determined. It is only assumed that God knows future events or, in a generalized version, that the value of the sentences about future events is 
set, and that they can be either true or false. Hence, if there is any causal connection, we can only admit that such knowledge or logical value is a consequence of an event.

At this stage, one should note that Grosseteste, within the list discussed above, does not explicitly distinguish cases of physical determinism: neither causal, including anticipants of modern mechanisms, nor teleological ones. It may be bothering. Although such ideas were not popular in the Middle Ages, they were expressed to some extent in ancient philosophy, especially by the ancient atomists, and it seems that a thinker as great and as well-educated as Robert, who quotes Cicero already in the first chapter of De libero arbitrio, should be familiar with them. However, it could be argued that in chapter 11, where Grosseteste discusses the topic of fate, he indeed refers to physical determinism. After his presentation of Boethius's concept of fate which relies on God's providence as its consequence, he invokes Cicero's definition of fate (cf. pp. 196-197). According to this ancient philosopher, fate is an order and a series of causes where one cause generates another one, and which flows from God who is an eternal truth and an eternal cause. Cicero argues that this meaning of fate should not be connected with superstition, but it is understood in a "natural sense" (physice). Furthermore, Robert also considers another, more "usual," understanding of fate as "the necessity of all lower things that stems from the ordering and turning of the celestial bodies," according to which "clearly everything would happen of necessity and nothing from freedom of decision" [pp. 198-199]. However, we should point out that when referring to Cicero, Robert is not concerned with the purely materialistic view, neither in the version represented by ancient atomists, nor in the teleological perspective of the Stoics, similarly to Marcus Tullius, who criticized both Epicureans and the Stoics for their materialism [19, p. 129]. Robert only considers a possibility that according to God's will the world is ordered by causal connections, and he does not limit them to the states of material objects. Thus, "physics" or "nature" is understood here in a wide sense, not restricted to the material world. What is crucial, Robert argues that some of the events are contingent and thus there is space to include LA. Hence, he indeed avoids considering the causal order in a materialistic manner.

There could be, of course, several reasons for him to exclude this option. He could have treated it as not a serious option. But, at the same time, he took into account an idea such as fate to discuss it and show that it can be understood "seriously," as in the case of Boethius or Cicero. He also could have assumed that if we accept physical determinism, there is no place for LA, so there is nothing to discuss. However, Epicurus's approach revealed that it is possible to combine the concepts of atomism and physical determinism with free will. Finally, one could point out that he intended his treatise to be a theological one, so if he assumed that God created the world and human beings as free creatures with rational souls (cf. pp. 200201), we should exclude physical determinism. But, if so, he should not be questioning the possibility of free actions and free decisions at all. Finally, we could claim that, following Aristotle, he could have taken it for granted that within the chain of causes we should include acts of the substances which have souls as their principle of movement, hence: independent from external principles, so he found it useless to discuss if souls could be subjected to physical-material determinants. However, it seems that the question about his reasons for not putting this kind of determinism on the above-mentioned list remains open.

In any case, if we want to make use of the list of the kinds of determination presented by Grosseteste, we can supplement it by adding causal determinism understood in a materialistic manner as one of the options of "physical" determinism labelled as fate, together with a materialistic version of teleological determinism, as viewed by the Stoics.

Finally, let us note that some of the options from Grosseteste's list, understood according to his interpretation - are not mutually exclusive. For instance, determination based on foreknowledge, so (1), is compatible with all of the other options. Similarly in the case of determination based on predestination, so (2), if we assume that fate, so (3), is understood - 
following Grosseteste's view - as compatible with or even as a result of God's will. It also seems that (3) may be compatible with (4) and with (5), for two reasons: (1) the causal arrangement of events, that is - fate, does not interfere with the moral, theological or supernatural qualification of certain deeds, (2) even if a deed is causally determined, it can still be confirmed by the consent of the person performing such a deed.

\section{Kinds of Necessity}

It is interesting that Grosseteste uses the words "necessity" and "necessary" in many contexts. In chapter 1, when he analyzes the central syllogism:

Everything known by God is or was or will be; $a$ is known by God (let $a$ be a future contingent); so $a$ is or was or will be [p. 111],

he speaks about the necessity of sentences belonging to this syllogism. First, he assumes that both premises are necessary ("utraque praemissarum est necessaria" [p. 110]). Then he states that if the premises are necessary, then the conclusion is not just true, but also necessary ("conclusio non solum vera, sed etiam necessaria" [p. 110]). This juxtaposition of the truth and the necessity of the sentence shows that he speaks about the necessity of sentences in terms of modal logic.

Moreover, he formulates there an interesting rule of a modal logic which he applies in his considerations: "Ex necessariis enim non sequitur nisi necessarium" [p. 110]. "Non sequitur nisi" means that it is necessary that one follows from another. This means that if $Y$ follows from $X$, and $X$ is necessary, then it is necessary that $Y$ is necessary. We could put it as follows:

$$
(\square X \rightarrow Y) \rightarrow \square(\square X \rightarrow \square Y)
$$

This rule tells us that in a syllogism which is well-constructed, which guarantees the necessity of the inference, necessity of the premises is transferred to the conclusion. Thus in the literature it is referred to as "Transfer of Necessity Principle" (cf. [28]). We should stress that this rule or principle does not have a metaphysical/ontological character, but a logical one. It is clear especially in the case of Grosseteste who, in the cited passage, speaks about the logical inference and the transfer of necessity from premises to a conclusion.

Incidentally, one could doubt whether Robert is actually referring to the necessity of the inference itself, which in the example given above was assumed on the basis of the phrase "non sequitur nisi." But the answer is definitely yes, as he states explicitly that when each of the premises is necessary, the inference is necessary ("patet etiam quod consecutio est necessaria" [p. 110]). It is confirmed by other examples as well. For instance, in a discussion conducted further in the text (chapter 4), we find the phrase: "possem necessario inferre: Socrates est; ergo Socrates est albus" [p. 126). It means that it is natural to him that, in the case of a well-constructed syllogism, the inference is necessary.

However, in chapter 2, he refers to another kind of necessity which can be considered a metaphysical one. There, he argues that God cognizes singular events (singularia). In one of the discussed arguments we read: "cum sit singularium creator, de necessitate cognoscit ipsa" [p. 116]. In this case, necessity is not transferred from another sentence on the basis of a syllogism. The necessity of the fact that God cognizes singular things is a consequence of the fact that God had created them, so we are dealing here with a metaphysical entanglement concerning a rational substance (in this case God) which intentionally creates something: 
when $x$ intentionally creates $y, x$ cognizes $y$. It simply results from a necessity which concerns beings.

Robert used this approach after his presentation of a list of arguments concerning the necessity of God's knowledge, concluded by a reflection that "what is contingent does indeed follow from things that are necessary" [p. 129]. At the same time, he pointed out that such a conclusion "goes against the art" [p. 129] in light of the syllogism presented above. However, he explained that "it seems that not only is it possible for what is contingent to follow from things that are necessary, but that this also is necessary"; referring to arguments of such authors as Augustine, Boethius, Seneca (addressing "forms, which Plato calls Ideas") and Anselm of Canterbury, he shows that there is a relationship between necessary reasons (rationes), e.g. in God's mind, which are "eternal, stable and unchangeable," and things that are "temporal, changeable, corruptible, and contingent," such that these contingent things "flow" from those necessary reasons [p. 131]. It shows that Robert adopted here a metaphysical approach and started considering properties of different kinds of beings. In this view, it is crucial whether a being itself is metaphysically necessary or contingent.

On this basis, he formulates his main solution concerning the concept of necessity, which is very similar in both recensions; however, in the earlier one it is preceded by direct references to the distinctions proposed by Boethius and by Anselm of Canterbury (cf. [11, pp. 139-140]). First, after Anselm, he distinguishes:

1) precedent necessity (necessitas praecedens), which is - as Grosseteste puts it - "a cause of a thing's existence and forces the thing to exist";

2) sequent necessity (necessitas sequens), which is not such a cause and "does not force a thing to exist," "which produces nothing" and just "seems to destroy alternatives" (as it refers to what is contingent), e.g. "while I am sitting, it is necessary that I am sitting" [pp. 22-25] in this case the alternative "I am sitting or I am not sitting" is destroyed.

Next, he reformulates the two kinds of necessity and calls them:

1) necessity from which "only what is necessary follows";

2) necessity from which "what is contingent seems to (videtur) follow."

Then, he refers to Boethius and says that, in his opinion, these kinds of necessities were called by Boethius: simple necessity (necessitas simplex) and necessity of condition (necessitas condicionis) [pp. 24-25], where an example of the first one is that it is necessary that all human beings are mortal, and an example of the latter is that if we see someone walking it is necessary that he/she is walking (Boethius, De consolatione philosophiae, V.6; cf. [2, p. 148]). ${ }^{1}$ Robert underlines that there are some who mean something else by necessity of condition, namely necessity of consecution of the consequent from the antecedent, but in fact ("in more depth") Boethius refers there to what Robert calls sequent necessity.

Now, in both recensions Grosseteste presents, in a very similar way (so I will now quote the later recension again), a crucial division, according to which something may be:

1) necessary "unqualifiedly" (simpliciter), which means that "it has no capacity (posse) at all for its opposite, either with or without a beginning," e.g. "that two and three are five";

2) necessary in a way that "it has no capacity for its opposite in respect of the past, present, or future, yet without a beginning there was a capacity for it and a capacity for its opposite" [pp. 134-135].

What may be most puzzling here is the expression "without a beginning." We should note that it refers to a sort of pre-temporal ("before time") or even atemporal perspective, in which we abstract from time and from the fact that a thing started to exist (had a beginning) or even from the fact that anything started to exist (as it can refer to the whole world). This idea seems to be connected with the Augustinian and Boethian concept of eternity, according to which God is not subject to change and time, and sees everything at once (which explains why Robert also uses the double expression: "from eternity and without a beginning"). Both 
authors are often quoted by him, also in this respect. In chapter 2, Grosseteste refers to Book V of Boethius's De consolatione (in which "the last Roman" formulated his famous definition of eternity: "aeternitas igitur est interminabilis vitae tota simul et perfecta possessio") and quotes some passages, including the one about God's "single mental glance" and the one according to which "God sees at present the future things" [pp. 114-115]. And in chapter 3, among many passages from Augustine, he quotes the one from Confessiones (XII, 15) about God's will being unchangeable, in which the bishop of Hippo states that "everything changeable is not eternal, but God is eternal" [pp. 124-125]. It means that God does not "live" in time and sees all the past, present and future events at once. According to Robert's abovementioned expression, it also includes a perspective in which such events are still not actualized, they are still possible.

In this context, Grosseteste shows that there are such propositions or dicta that if their truth is established, it cannot cease (their truth will not have "non-being after being"), so they do not have the capacity for their opposites (as "they cannot be altered from being true to being false"), but if we abstract from the fact that they are already true and adopt an eternal, atemporal perspective, they still have such a capacity. As Robert explains, the dictum "that Antichrist will be going to exist" is true in respect of the past, the present and the future, as it has no capacity for its opposite, but "without a beginning" it does have such a capacity. So for such dicta, as well as for some true dicta about the future (e.g. given in prophecy), "from eternity and without a beginning" there is a capacity to have been true and a capacity to have been false. And, in this sense, things that such dicta are about are contingent (cf. pp. 134135). So if "God knows $a$ " is true, then it cannot become false, and in this way it is necessary. The same situation arises when we consider the conclusion of a syllogism drawn from such true (so: necessary) propositions. However, from the perspective "without a beginning," the opposite is possible, and in this way $a$ is contingent.

On this basis Robert discerns:

1) necessity in the sense that the truth of the sentence cannot cease;

2) necessity of existence.

In this light, he claims that "Antichrist necessarily is going to exist" has two interpretations, as the necessity can apply to:

1) "the futurity attributed to Antichrist, and in this sense it is true and follows by syllogistic inference from premises that are necessary in the same sense";

2) "the existence of Antichrist, which is future, so that the sense is 'Antichrist will have in the future existence of necessity', and in this sense it is false and does not follow from any premises that are either true or necessary, for in the future he will have contingent existence" [pp. 136-137].

So he concludes that in such dicta "a certain contingency is combined with a certain necessity." Hence, he discerns three cases:

1) "total necessity" (omnino necessitas), as in "two and three are five";

2) "necessity in one respect and contingency in another," as in some true dicta about future contingents (or present or past), namely those whose truth cannot cease;

3) "total contingency" (omnino contingentia) in dicta which are true, but can become false, like "that Socrates is pale" (cf. pp. 136-137).

Finally, when speaking about contingency within the "without a beginning" perspective, Robert refers to the "contingency of things in themselves" (contingentia rerum in ipsis) (cf. pp. 138-139). So, in this case, he applies a clearly metaphysical approach.

To conclude, we should note that Grosseteste presented different distinctions in order to defend contingency, even if we accept a necessity following from God's foreknowledge or even omniscience, starting with the theories developed by Anselm of Canterbury and Boethius, and finally offering his own, original solution. Those earlier theories were based on 
the analysis of implication representing the connection between cause and effect, where if the occurrence of an effect means that its cause is necessary, it constitutes "sequent necessity" or "necessity of condition," which does not exclude the contingency of such a cause. However, Grosseteste decided to present a theory based on a concept of capacity for the opposite, which can be applied to sentences, propositions, dicta or things they are about. Their capacity for their opposites can be assessed from two perspectives: the one in which their truth or falsity is already established, and the one called "from eternity and without a beginning." Such a capacity viewed "without a beginning" is combined with the contingency of a thing in itself, which has a metaphysical character, whereas if such an incapacity is considered in respect of past, presence, or future, we can claim that it has a logical or epistemological character, as it is a consequence of an inference or of a cognition.

A juxtaposition of those two criteria (first: having such a capacity or not, second: the perspective adopted to asses it) gives us the three discussed options. It is obvious that Grosseteste excluded a fourth one, according to which a true dictum would have a capacity for its opposite in respect of time, but it would not have such a capacity "without a beginning."

\section{Usefulness in Contemporary Debates}

To illustrate the ways in which Grosseteste's theory can be useful in contemporary debates I will present selected examples, referring to the issues discussed by Professor Woleński.

A very important contribution to the debate concerning determinism is the division between holistic determinism and distributive determinism. The thesis of the former is the following: "The later states of the world are precisely determined by its earlier states." It is "holistic," as it concerns the world as a whole. Whereas the thesis of the latter is restricted to single events (so the world is treated in a distributive way): "For each event $z, z$ is precisely defined by a set of prior conditions" [27, p. 177]. It is clear that the first one excludes free decision. Professor Woleński underlines that its "rule" includes the cases of the acts of (more or less free) decision, so if we consider them as a part of the set of all earlier states of the later states, it may appear to be compatible with the existence of free decision. However, if we take into account that they are also a part of the later state of the world which is precisely determined, then we see that they cannot be free. But it is different in the case of distributive determinism. Here we can just include the acts of free choice as part of the prior conditions. It seems that we do not need to agree that such acts are also events which are precisely determined.

We should note that in Grosseteste's De libero arbitrio we can find examples which can illustrate both of these kinds of determinism. Fate, according to the second understanding, which he finds in Cicero, seems to be the case of holistic determinism, as this approach assumes that everything is necessary and the stars have precisely determined the states of the world. And it seems that, as Robert adopts natural causality (though including the acts of free decision), his general view is an example of distributive determinism. However, Grosseteste provides a wider perspective with his list of kinds of determination, which is important if we want to consider a theological perspective. Also in philosophical debates which include such a perspective it is important to take into account such realities as: sin, grace and God's preelection (predestination) and its relationship with LA. And Grosseteste provides a subtle discussion concerning all these levels of possible determination. I believe that in such debates it is essential to take into consideration as wide a range of kinds of determination as possible and not to restrict it to a specific case of determination. An example of such a general and broader approach with many types of determination (including: prospective, retrospective and functional ones), together with a reminder that we should not neglect this kind of perspective, has been presented for instance by Jacek J. Jadacki [9, p. 84]. 
Next, in contemporary debates on determinism and necessity it is important to establish relationships between such notions and their precise meanings. For instance, one can say that " $A$ is determined" is equal to " $A$ is necessary," and " $A$ is contingent" is equal to " $A$ is possible and $\neg A$ is possible," and also " $\neg A$ is determined" is equal to " $A$ is impossible", as Professor Woleński proposed (cf. [26, pp. 188-189]). However, it is possible to do it differently, for example by saying that contingency is expressed simply by the proposition " $A$ is possible" or "It is not true that $A$ is determined," and it is a matter of choice. What is more, such choices may be connected with additional assumptions, like the formal equivalence of the de re and de dicto interpretation (cf. [26, p. 185]), whatever such distinction would mean exactly, bearing in mind that we can find different approaches to this division.

Grosseteste provides a clear theory in which necessity is defined as incapacity for the opposite. It means that if something is necessary it has no capacity (or possibility - posse) for its opposite. And something is contingent when it has such a capacity (so: possibility). This category is universal, as it may be applied - as Robert shows - to different perspectives, like: (1) as referred to the past, presence or future, in which the truth/falsity of the dictum can be already established, (2) "without a beginning and from eternity." It seems that his theory may be easily translated into the theory of possible worlds in the following way: necessity in (1) is necessity in an actual (or a chosen) world, whereas necessity in (2) is necessity in every possible world. At least for these reasons it is worth referring to Grosseteste's theory when establishing the meaning of these notions in our debates.

Furthermore, Robert's approach may deepen such debates by introducing (with the above-mentioned perspectives) two important dimensions. It can, for instance, shed a new light on the following simple triad of possible relationships between the notions of actuality and determination:

(a) if $A$ is actual, $A$ is determined;

(b) if $A$ is actual, $A$ is contingent;

(c) if $A$ is actual, $A$ is determined or $A$ is contingent.

According to Jan Woleński these represent respectively: radical determinism (RD), radical indeterminism (RI) and together moderate determinism (MD) and moderate indeterminism (MI), which are formally indistinguishable [26, p. 188]. When we do not include those two perspectives, we rather interpret "or" in (c) as a disjunction (so "XOR"): $A$ can be determined or contingent, but it cannot be both determined and contingent. By contrast, the juxtaposition of those two perspectives, offered by Robert, produces an option such that $A$ is actual and $A$ is both determined (according to (1)) and contingent (according to (2)). This approach generates the following matrix of positions, where (1) and (2) indicate the above-mentioned perspectives:
(a) $\mathrm{RD}(1)-\mathrm{RD}(2)$;
(a') $\mathrm{RD}(1)-\mathrm{MD} / \mathrm{MI}(2)$;
(a") $\mathrm{RD}(1)-\mathrm{RI}(2)$;
(b) $\mathrm{RI}(1)-\mathrm{RD}(2)$;
(b') RI(1)-MI/MD(2);
(b") RI(1)-RI(2);
(c) $\mathrm{MD} / \mathrm{MI}(1)-\mathrm{RD}(2)$;
(c') MD/MI(1)-RI(2);
(c") MD/MI(1)-MD/MI(2). 
The position that Robert represents is, of course, $\left(a^{\prime}\right)$, as God knows about every state of affairs (in this way they are actual), so for him in (1) their truthfulness is established (and in this way they are determined), but in (2) some of these states of affairs are necessary and some are contingent. According to Grosseteste's approach, (b) - $\left(b^{\prime \prime}\right)$ would mean that God knows nothing about the world. Those options could represent Aristotle's theory where God thinks about himself only or a position that God does not think or know anything, or simply atheism. What is more, to accept $(b)-\left(b^{\prime \prime}\right)$ we would have to admit that not only the sentences about future events would not be determined, but also all the sentences about the past and the present ones. Perhaps, we could label such a position as a kind of radical skepticism. And (c) - $\left(c^{\prime \prime}\right)$ mean that if there is God, his knowledge is partial. Perhaps, there can be other interpretations of the options presented above, and for sure there are many interesting problems arising from such a matrix, but this deserves a separate discussion.

Finally, when talking about God's omniscience, it is very easy to slip into a deterministic perspective, from which it is very difficult to see any solution defending the possibility of free decision. Professor Woleński has rightly pointed out that, in terms of such omniscience, there is no difference between foreknowledge and knowledge, in particular between truths about the past and truths about the future. On this basis he concluded:

This, in turn, means that the set of future contingents in this situation is empty - also because divine knowledge is necessary. The problem for the theologian is that, if the world was created by God, fatalism with reference to human choices seems to be unavoidable [26, p. 193].

Grosseteste's great effort was to show that such fatalism is indeed avoidable. But at the same time, he was aware that debates on this topic are often connected with a presupposition concerning incompatibility. He indicated the source of the problem as follows:

So the fog that surrounds these matters is wholly a product of the fact the contingency of things in themselves seems to be incompatible with their necessity in the divine mind and knowledge [...]. It is also a product of the fact that it is not distinguished how in the same proposition in one respect there is necessity [...] and in another respect contingency [p. 139].

And in my opinion he really did provide a well-constructed theory and argumentation to defend the compatibility of LA and God's omniscience. Therefore, this is another reason to refer to his work anytime we start a debate on these topics.

\section{Conclusions}

Robert Grosseteste presented a wide range of different kinds of determination of human actions and used the notion of necessity in various contexts, showing the richness of it.

He elaborated an original theory of necessity and contingency based on the concept of capacity for the opposite and two perspectives: (1) being true in respect of the past, present or future and (2) without a beginning and from eternity. This enabled him to explain that determination which follows from the fact that something is true does not exclude contingency, and in consequence to defend the compatibility of God's omniscience and human free decision.

His interpretations and his theory can be useful in contemporary debates. They widen the scope of analyses by adding the "theological" aspects of determination. They provide precise definitions of necessity and contingency, which are a good analytical tool and which can be translated into the concept of possible worlds. Through their two-perspectives 
approach they enrich the range of options by generating nine kinds of positions on the spectrum of determinism and indeterminism.

It seems that his solution should be taken into account anytime philosophers discuss the topic of determination, particularly determination of the past (or present or future), or of the compatibility of God's omniscience and human free decision. In many situations it may turn out that contemporary arguments concerning these topics are weak or insufficient in confrontation with Grosseteste's solution.

\section{Acknowledgments}

This article was supported by the National Science Centre, Poland, under grant agreement No. 2015/18/E/HS1/00153.

\section{References}

1. Andreoletti, G. Fatalism and Future Contingents, Analytic Philosophy 60 (3), 2019, pp. 245-258.

2. Boethius. Consolation of Philosophy, transl. by J. C. Relihan, Indianapolis and Cambridge: Hackett Publishing, 2001.

3. Ciuni, R., and C. Proietti. The Abundance of the Future: A Paraconsistent Approach to Future Contingents, Logic and Logical Philosophy 22, 2013, pp. 21-43.

4. Ciuni, R., and C. Proietti. Future Contingents, Supervaluations, and Relative Truth, In L. Bellotti, L. Gili, E. Moriconi, and G. Turbanti (eds.), Third Pisa Colloquium in Logic, Language and Epistemology: Essays in Honour of Mauro Mariani and Carlo Marletti, Pisa: Edizioni ETS, 2019, pp. 69-88.

5. Crombie, A. C. Robert Grosseteste and the Origins of Experimental Science 1100-1700, Oxford: Clarendon Press, 1953.

6. Dawson, J. G. Necessity and Contingency in the De libero arbitrio of Grosseteste, In La filosofia della natura nel Medioevo: Atti del terzo Congresso internazionale di filosofia Medioevale, Passo della Mendola (Trento) 31 agosto-5 settembre 1964, Milan: Società editrice Vita e pensiero, 1966, pp. 357-362.

7. Di Nucci, E. Knowing Future Contingents, Logos and Episteme 3 (1), 2012, pp. 43-50.

8. Iwanicki, M. Divine Foreknowledge and Human Freedom: N. Pike contra A. Plantinga, In A. P. Stefańczyk and R. Majeran (eds.), If God Exists... Human Freedom and Theistic Hypothesis: Studies and Essays, Lublin: Towarzystwo Naukowe KUL, 2019, pp. 425-462.

9. Jadacki, J. J. Causal and Functional Determination vs. Foreknowledge about the Future, Roczniki Filozoficzne 66 (4), 2018, pp. 81-98.

10. Jadacki, J. J. O antynomii zdarzeń przyszłych, Przegląd Filozoficzny 3 (99), 2016, pp. 311-329.

11. Kijewska, A. Robert Grosseteste and His De Libero Arbitrio, In A. P. Stefańczyk and R. Majeran (eds.), If God Exists... Human Freedom and Theistic Hypothesis: Studies and Essays, Lublin: Towarzystwo Naukowe KUL, 2019, pp. 133-149.

12. Knuuttila, S. Medieval Approaches to Future Contingents, Roczniki Filozoficzne 66 (4), 2018, pp. 99-114.

13. Lewis, N. The First Recension of Robert Grosseteste's De libero arbitrio, Mediaeval Studies 53, 1991, pp. 1-88.

14. Lewis, N. Introduction, In Robert Grosseteste, On Free Decision, N. Lewis (ed.), Auctores Britannici Medii Aevi, Oxford: Oxford University Press, 2017, pp. xiii-cxvi. 
15. Lewis, N. Libertas arbitrii in Robert Grosseteste's De libero arbitrio, In J. Flood, J. R. Ginther, and J. W. Goering (eds.), Robert Grosseteste and His Intellectual Milieu: New Editions and Studies, Papers in Mediaeval Studies 24, Toronto: PIMS, 2013.

16. Łukasiewicz, D. Marcin Tkaczyk's Ockhamism, or Whether the Theory of Contingentia Praeterita is the only Plausible Solution to the Problem of Futura Contingentia, Roczniki Filozoficzne 66 (4), 2018, pp. 115-134.

17. Pawl, T. A Reply to "The Antinomy of Future Contingent Events", Roczniki Filozoficzne 66 (4), 2018, pp. 149-157.

18. Robert Grosseteste. On Free Decision, N. Lewis (ed.), Auctores Britannici Medii Aevi, Oxford: Oxford University Press, 2017.

19. Smith, G. B. Political Philosophy and the Republican Future: Reconsidering Cicero, Notre Dame, IN: University of Notre Dame Press, 2018.

20. Tkaczyk, M. The Antinomy of Future Contingent Events, Roczniki Filozoficzne 66 (4), 2018, pp. 5-38.

21. Tkaczyk, M. Futura Contingentia, Lublin: Wydawnictwo KUL, 2015.

22. Todd, P., and B. Rabern. Future Contingents and the Logic of Temporal Omniscience, Nous 2019, pp. 1-26.

23. Wawer, J. Branching Time and the Semantics of Future Contingents, PhD dissertation, Kraków, 2016.

24. Wciórka, W. Mitigating the Necessity of the Past in the Second Half of the Twelfth Century: Future-Dependent Predestination, Vivarium 58, 2020, pp. 29-64.

25. Wojtysiak, J. Future Contingents, Ockhamism (Retroactivism) and Thomism (Eternalism), Roczniki Filozoficzne 66 (4), 2018, pp. 159-182.

26. Woleński, J. Is the Past Determined (Necessary)? Roczniki Filozoficzne 66 (4), 2018, pp. 183-195.

27. Woleński, J. Wolność, determinizm, indeterminizm, odpowiedzialność, Ślaskie Studia Historyczno-Teologiczne 29, 1996, pp. 176-179.

28. Zagzebski, L., Foreknowledge and Free Will, In E. N. Zalta (ed.), The Stanford

Encyclopedia of Philosophy (Summer 2017 Edition),

https://plato.stanford.edu/archives/sum2017/entries/free-will-foreknowledge/.

\section{Notes}

1. In the later recension those concepts are used only in the solutions to the other problems, such as free decision and predestination, cf. pp. 184-185: "Accordingly, our reply is that predestination in fact is a necessary cause and has a necessary effect. But it is not an unqualifiedly necessary cause (non simpliciter), but conditionally (condicionaliter) [necessary], and it has subsequent rather than precedent necessity." 